\title{
OPTIMIZATION OF MECHANICAL BEHAVIOR OF NI-P NANOCOMPOSITE COATINGS USING TAGUCHI APPROACH
}

\author{
MUROOG M. SHINYAR ${ }^{1}$, LAITH K. ABBAS ${ }^{2}$ \& ABBAS KHAMMAS HUSSEIN ${ }^{3}$ \\ ${ }^{1,2}$ Department of Materials Engineering, University of Technology, Baghdad, Iraq
}

${ }^{3}$ Nanotechnology and advanced materials research center, University of Technology, Baghdad, Iraq

\begin{abstract}
This paper studies the electroless (Ni-P) deposition which used in different engineering applications due to their ability to modify and enhance the surface properties of the steel substrate. The electroless plating process was used to prepare (Ni-P/Nano TiO2), (Ni-P/Nano Al2O3) and (Ni-P/Nano SiO2) alloys in this research. Deposition process parameters based on (L28) Taguchi orthogonal configuration with three process parameters, viz, stirring speed, temperature, time, are designed for optimum microhardness. Under the Taguchi series, the microhardness activity of electroless (Ni-P-TiO2) nanocomposite deposition was measured. The findings revealed that the integration of TiO2 into the coating allows micro-hardness to increase. Finally, optimum conditions were achieved as, A2B1C2 (i.e. middle-level of bath temperature $\left(90^{\circ} \mathrm{C}\right)$, lower level of plating time (80 min.) and middle level of nanomaterial (Al2O3)), the ANOVA analysis reveals that nanomaterial has a great (60\%) influence over the microhardness and surface roughness as compared to bath temperature (28\%) and plating time (12\%).

KEYWORDS: Nanocomposite Coatings, Mechanical properties, Taguchi Method
\end{abstract}

Received: Dec 20, 2020; Accepted: Jan 10, 2021; Published: Jan 21, 2021; Paper Id.: IJMPERDFEB20219

\section{INTRODUCTION}

Generally, deposition of Electroless nickel-phosphorus has been examined because it became to start with defined through Brenner and Riddell in 1946 [1]. The electroless Ni-P alloys are usually utilized in different engineering applications for their typical mechanical and physical properties such as excellent wear, abrasion and corrosion resistance, ductility, soldering, lubrication, and electric properties in addition to low cost of material [2-3]. Among the electro-plating techniques, electroless deposition has more advantages because of its low device cost, easy in operation, and the formation capacity of very thin and uniform coating on each conductive and non-conductive surfaces. [4-5]. Electroless plating is an autocatalytic method. In this process the reduction of the metal ions and coating deposition may be done via the oxidation of the lowering agent, which materials an electric powered. The substrate develops ability while it is dipped in electroless solution known as electroless bath, which includes a supply of metal ions, reducing agent, complexing agent, stabilizer, additives, and wetting agents etc. Due to the advanced ability, each positive and negative ions are attracted in the direction of the substrate surface and release their energy via charge transfer method The prime characteristic of clectroless nickel-phosphorus coating is the uniform deposition of coating on metal (ferrous and non-ferrous) substrate. Electroless coatings can widley be classified into four categories viz, pure nickel and black nickel coating, alloy and poly-alloy coatings, composite coatings and electroless nano coatings. Electroless plating has highly consistent thickness across all surfaces, such as edges and complex interior geometry [6]. With current advances in nanoparticles technology and their applications in different fields [7], 
also, they were used as an additive in electroless $\mathrm{Ni} / \mathrm{P}$ plating. Composite coating is ready with the aid of using including solid particles alumina, titanium oxide, silicon carbide, silicon nitride, carbon nanotube into electroless coating solution [8]. These coatings show higher physico-mechanical properties compared with plane Ni/P electroless coatings. One of the prime properties which has proved to be of significance in successful applications is hardness [9]. Surface hardness is especially essential for the control of tear and wear methods in components or products. The hardness of the electroless deposition will increase with the heat treatment to a certain temperature [10]. The microhardness of the surface has a extensive effect on mechanical properties including fatigue behavior, resistance to corrosion and creep life. As a result, development in the modeling of surface microhardness and optimization of control parameters is required to achieve the desired degree of surface microhardness. It is therefore necessary to maximize the mean microhardness of the products [11-12]. In composite coatings surface roughness performs very essential role because it influences on porosity of coating. Due to higher porosity the corrosion resistance of the composite coating can be reduced. Hence it is important to reduce or control the surface roughness of coated samples. In this research, the Taguchi technique become used for optimization [13-14]. The aim of this research is to improve the mechanical properties of the low carbon steel substrate by coating it electrolessly with Ni-P-TiO2, Ni-P$\mathrm{Al} 2 \mathrm{O} 3$ and Ni-P- $\mathrm{SiO} 2$ coating and find the optimal coating conditions.

\section{EXPERIMENTAL}

\subsection{Substrate deposition and preparation:}

Low carbon steel samples with the dimensions $(1.5 \mathrm{~cm} \times 1.5 \mathrm{~cm} \times 0.5 \mathrm{~cm})$ were used as substrates. The chemical structure of the low carbon steel shows in the table (1) by using Spectra Max at (The General Company for Engineering Inspection and Rehabilitation):

Table 1: Chemical composition of Low carbon steel

\begin{tabular}{|l|l|l|l|l|l|l|l|l|l|l|l|}
\hline Element & $\mathbf{C}$ & $\mathbf{S i}$ & $\mathbf{M o}$ & $\mathbf{S}$ & $\mathbf{P}$ & $\mathbf{N i}$ & $\mathbf{M n}$ & $\mathbf{A l}$ & $\mathbf{C r}$ & $\mathbf{P b}$ & $\mathbf{F e}$ \\
\hline $\mathrm{Wt} \%$ & 0.139 & 0.0072 & 0.002 & 0.0053 & 0.0088 & 0.0324 & 0.526 & 0.0522 & 0.0044 & 0.0030 & Bal \\
\hline
\end{tabular}

Then specimens washed at room temperature in an alkaline solution $(1 \mathrm{M} \mathrm{KOH})$ after which successively rinsed with suitable deionized waters for 15 minutes. Before the deposition, the steel sample cleaning is accomplished as follows The samples had been mechanically polished to (2000) grade with emery papers, and carefully processed at a (50\%) dilute $(\mathrm{HCl})$ solution. Specimens had been washed with water, dried manually through a piece of cotton after which washed through methanol. Samples after washing with methanol had been rinsed and dried in an oven. The samples then had been immersed in the (Ni-P) deposition bath instantly. Table (2) shows the tank composition for the (Ni-P) Nano (TiO2) electroless deposition. The tank is run at $\left(80^{\circ} \mathrm{C}\right.$ to $\left.100^{\circ} \mathrm{C}\right)$ with a $(\mathrm{pH}=5)$ solution for $(40$ minutes to 120 minutes) of plating time.

Table 2: Bath composition for (Ni-P) Nano $\left(\mathrm{TiO}_{2}\right)$ deposition.

\begin{tabular}{|l|l|}
\hline \multicolumn{1}{|c|}{ Substance } & \multicolumn{1}{c|}{ Concentration (g/L) } \\
\hline $\mathrm{NiSO}_{4} \cdot 6 \mathrm{H}_{2} \mathrm{O}$ & 30 \\
\hline $\mathrm{NaH}_{2} \mathrm{PO}_{2}$ & 25 \\
\hline
\end{tabular}




\begin{tabular}{|l|l|}
\hline $\mathrm{Na}_{3} \mathrm{C}_{6} \mathrm{H}_{5} \mathrm{O}_{7} . \mathrm{H}_{2} \mathrm{O}$ & 20 \\
\hline Thiourea & 0.002 \\
\hline Nano $\mathrm{TiO}_{2}$ & 3 \\
\hline
\end{tabular}

Table (3) shows the bath of composition for (Ni-P) Nano (A12O3) electroless deposition. The bath was worked at $\left(80{ }^{\circ} \mathrm{C}\right.$ to $\left.100{ }^{\circ} \mathrm{C}\right)$ with a $(\mathrm{pH}=5)$ solution for $(40$ minutes to 120 minutes $)$ of plating time.

Table 3: Bath composition for (Ni-P) Nano (Al2O3) deposition.

\begin{tabular}{|l|l|}
\hline \multicolumn{1}{|c|}{ Substance } & \multicolumn{1}{c|}{ Concentration (g/L) } \\
\hline $\mathrm{NiSO}_{4} \cdot 6 \mathrm{H}_{2} \mathrm{O}$ & 30 \\
\hline $\mathrm{NaH}_{2} \mathrm{PO}_{2}$ & 25 \\
\hline $\mathrm{Na}_{3} \mathrm{C}_{6} \mathrm{H}_{5} \mathrm{O}_{7} \cdot \mathrm{H}_{2} \mathrm{O}$ & 20 \\
\hline Thiourea & 0.002 \\
\hline Nano $\mathrm{AL}_{2} \mathrm{O}_{3}$ & 3 \\
\hline
\end{tabular}

Table (4) shows the bath of composition for (Ni-P) Nano (SiO2) electroless deposition. The bath was worked at (80 ${ }^{\circ} \mathrm{C}$ to $\left.100{ }^{\circ} \mathrm{C}\right)$ with a $(\mathrm{pH}=5)$ solution for (40 minutes to 120 minutes) of plating time.

Table 4: Bath composition for (Ni-P) Nano (SiO2) deposition

\begin{tabular}{|l|l|}
\hline \multicolumn{1}{|c|}{ Substance } & \multicolumn{1}{c|}{ Concentration (g/L) } \\
\hline $\mathrm{NiSO}_{4} \cdot 6 \mathrm{H}_{2} \mathrm{O}$ & 30 \\
\hline $\mathrm{NaH}_{2} \mathrm{PO}_{2}$ & 25 \\
\hline $\mathrm{Na}_{3} \mathrm{C}_{6} \mathrm{H}_{5} \mathrm{O}_{7} \cdot \mathrm{H}_{2} \mathrm{O}$ & 20 \\
\hline Thiourea & 0.002 \\
\hline Nano $\mathrm{SiO}_{2}$ & 3 \\
\hline
\end{tabular}

In each experiment, $(200 \mathrm{~mL})$ of fresh bath solution was selected.

\subsection{Microhardness measurements}

For evaluating the microhardness of electroless (Ni-P) Nano (TiO2), (Ni-P) Nano (Al2O3) and (Ni-P) Nano (SiO2) coatings, a microhardness tester with a Vickers indenter was used. To cause the indentations in all deposits, a constant load of $100 \mathrm{~g}$ was applied and the hardness values were averaged out of three such determination. The test was done in (Department of Materials Engineering - University of Technology - Baghdad - Iraq), as shown in figure (1): 


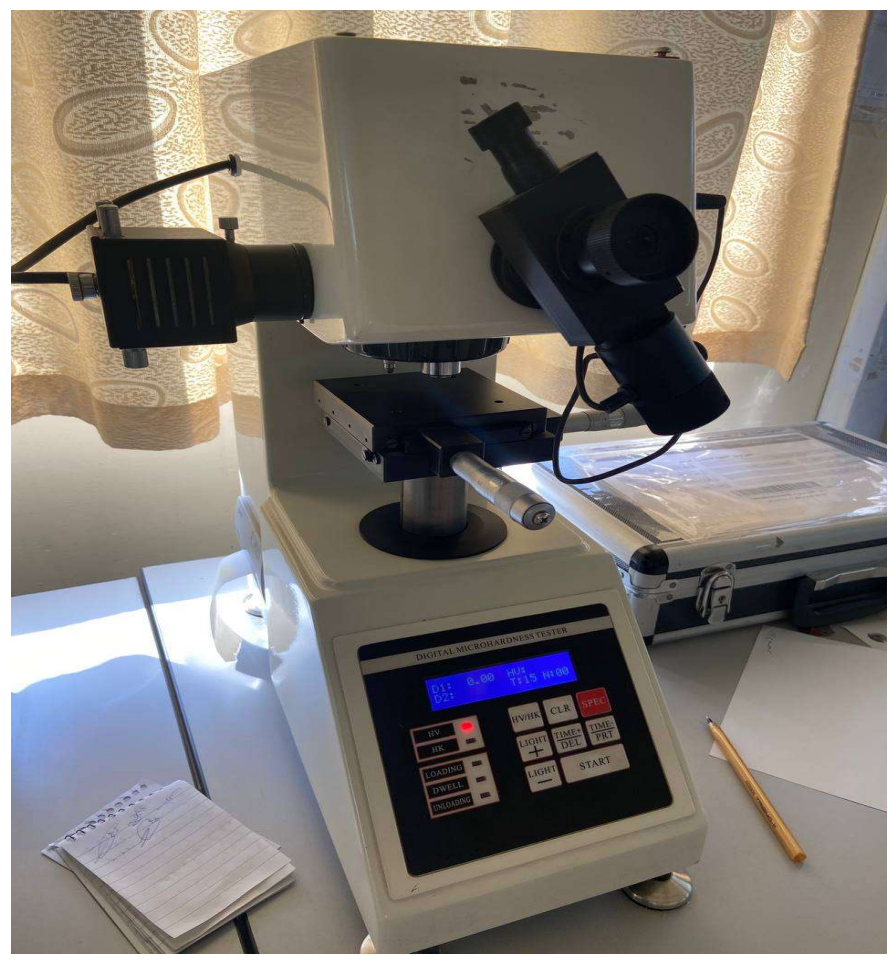

Figure 1: Microhardness test device.

\subsection{Taguchi Method}

Design of Experiments (DOE) is based on the objective of desensitizing a product's performance characteristic(s) to variation in critical product and process design parameters. Through DOE, a series of tests are performed where preplanned changes are made to the controllable variables so that the reason for changes in the response can be observed and identified. When DOE is performed using Taguchi method, the latter generally relates the variability in the responses of a particular trial condition with the effect of the uncontrollable variables or noise. Taguchi method obtains the optimal condition by observing the reduction in variation of the results within a particular trial condition. Hence, to take into account the variation of results, Taguchi method uses the $\mathrm{S} / \mathrm{N}$ ratio to identify the quality characteristics applied for engineering design problems. In the $\mathrm{S} / \mathrm{N}$ ratio, signal is interpreted as mean while noise is interpreted as standard deviation.

It is found that the characteristics of electroless coating get affected by several factors such as bath temperature, plating time, coating composition using nanomaterial, stabilizer concentration, $\mathrm{pH}$ of the solution, substrate, bath load, etc. Consideration of all the factors would make the experimental design highly complex and the analysis even more complicated. A review of the recent literatures revealed that the three factors viz. bath temperature (A), plating time (B) and coating composition using nanomaterials (C) are the mostly preferred factors used by the researchers to control the properties of electroless nickel deposits. The bath temperature initiates the reaction mechanism and thereby determines the rate of reaction by controlling the ionization and charge transfer process. The considered design parameters, together with their levels are shown in Table 5. Consideration of three levels allows the study of non-linear effects if any. 
Table 5: Design parameters and their levels

\begin{tabular}{|l|l|l|l|l|}
\hline \multirow{2}{*}{ Design Factors } & \multicolumn{2}{c|}{ Unit } & \multicolumn{3}{c|}{ Levels } \\
\cline { 3 - 6 } & & \multicolumn{2}{c|}{$\mathbf{2}$} & \multicolumn{2}{c|}{$\mathbf{2}$} & \multicolumn{1}{c|}{3} \\
\hline Bath temperature A & ${ }^{\circ} \mathrm{C}$ & 80 & 90 & 100 \\
\hline Plating time B & Min. & 40 & 80 & 120 \\
\hline Nano-material C & - & $\mathrm{TiO}_{2}$ & $\mathrm{Al}_{2} \mathrm{O}_{3}$ & $\mathrm{SiO}_{2}$ \\
\hline
\end{tabular}

In the present article, microhardness and roughness of electroless Ni-P coatings were studied. Hence, the two popularly evaluated parameters are considered as the response variables. A lower value of roughness and a higher value of hardness indicate that the material under test has a higher resistance against abrasive.

In the context of DOE, the number of degrees of freedom of a particular parameter is one less than the number of levels associated with the parameter. In the present case since each of the main factors is associated with three levels, the dof of each of the factors is two. It is important to notice that the number of experimental trials in the Orthogonal Array OA must be greater than the total dof required for studying the effects. Hence, $L 27$ OA. requiring twentyseven experimental runs is suitably chosen for the present case. The assignment of the factors to the columns of the array is done on the basis of the Triangular Table for 3-level OA. The $L_{27} \mathrm{OA}$ together with the column assignments are shown in Table 6. The values in each cell of the main parameter columns (A, B and C) in the array indicate their levels (1,2 and 3).

Table 6: $L 27$ orthogonal array with main parameters

\begin{tabular}{|l|l|l|l|l|}
\hline Exp.No. & \multicolumn{1}{|c|}{ Nano material } & \multicolumn{1}{|c|}{ Temperature } & Time & Speed of stirring \\
\hline 1 & Tio2 & 80 & 40 & 500 \\
\hline 2 & Tio2 & 80 & 80 & 500 \\
\hline 3 & Tio2 & 80 & 120 & 500 \\
\hline 4 & Tio2 & 90 & 40 & 500 \\
\hline 5 & Tio2 & 90 & 80 & 500 \\
\hline 6 & Tio2 & 90 & 120 & 500 \\
\hline 7 & Tio2 & 100 & 40 & 500 \\
\hline 8 & Tio2 & 100 & 80 & 500 \\
\hline
\end{tabular}




\begin{tabular}{|c|c|c|c|c|}
\hline 9 & Tio2 & 100 & 120 & 500 \\
\hline 10 & $\mathrm{~A} 12 \mathrm{o} 3$ & 80 & 40 & 500 \\
\hline 11 & Al2o3 & 80 & 80 & 500 \\
\hline 12 & $\mathrm{~A} 12 \mathrm{o} 3$ & 80 & 120 & 500 \\
\hline 13 & $\mathrm{~A} 12 \mathrm{o} 3$ & 90 & 40 & 500 \\
\hline 14 & $\mathrm{~A} 12 \mathrm{o} 3$ & 90 & 80 & 500 \\
\hline 15 & $\mathrm{~A} 12 \mathrm{o} 3$ & 90 & 120 & 500 \\
\hline 16 & $\mathrm{~A} 12 \mathrm{o} 3$ & 100 & 40 & 500 \\
\hline 17 & $\mathrm{Al} 2 \mathrm{o} 3$ & 100 & 80 & 500 \\
\hline 18 & $\mathrm{Al} 2 \mathrm{o} 3$ & 100 & 120 & 500 \\
\hline 19 & Sio2 & 80 & 40 & 500 \\
\hline 20 & Sio2 & 80 & 80 & 500 \\
\hline 21 & Sio2 & 80 & 120 & 500 \\
\hline 22 & Sio2 & 90 & 40 & 500 \\
\hline 23 & Sio2 & 90 & 80 & 500 \\
\hline 24 & Sio2 & 90 & 120 & 500 \\
\hline 25 & Sio2 & 100 & 40 & 500 \\
\hline 26 & Sio2 & 100 & 80 & 500 \\
\hline 27 & Sio2 & 100 & 120 & 500 \\
\hline
\end{tabular}

\section{RESULTS AND DISCUSSIONS}

Taguchi method needs to take into account the variability within a trial condition. The variability can be easily captured if $\mathrm{S} / \mathrm{N}$ ratio is used to convert the experimental results into a value for the evaluation characteristic in the optimum parameter 
analysis, instead of the mean. The idea is to maximize the $\mathrm{S} / \mathrm{N}$ ratio, thereby minimizing the effect of random noise factors, which have a significant impact on the process performance. In the present work $\mathrm{S} / \mathrm{N}$ ratio analysis is done with microhardness and roughness as the performance index and all the calculations are conducted in Minitab, where microhardness is to be maximized and roughness is to be minimized, $\mathrm{S} / \mathrm{N}$ ratio.

The microhardness and roughness values obtained from experimentation along with their $\mathrm{S} / \mathrm{N}$ ratios is shown in Table 7.

Table 7: Experimental results along with $\mathrm{S} / \mathrm{N}$ ratio

\begin{tabular}{|c|c|c|c|c|c|c|c|}
\hline Exp.No. & $\begin{array}{l}\text { Nano } \\
\text { material }\end{array}$ & Temperature & Time & \begin{tabular}{ll|} 
Speed & of \\
stirring & \\
\end{tabular} & Microhardness & Roughness & $\mathrm{S} / \mathrm{N}$ ratio \\
\hline 1 & Tio2 & 80 & 40 & 500 & 201.4 & 0.9395 & -2.92926 \\
\hline 2 & Tio2 & 80 & 80 & 500 & 265.8 & 0.7195 & -2.96328 \\
\hline 3 & Tio2 & 80 & 120 & 500 & 274.3666667 & 0.9695 & -2.94891 \\
\hline 4 & Tio2 & 90 & 40 & 500 & 221.3333333 & 1.3335 & -2.90564 \\
\hline 5 & Tio2 & 90 & 80 & 500 & 417.8666667 & 0.748 & -2.9792 \\
\hline 6 & Tio2 & 90 & 120 & 500 & 254.5 & 1.6805 & -2.89559 \\
\hline 7 & Tio2 & 100 & 40 & 500 & 340.1333333 & 1.474 & -2.93502 \\
\hline 8 & Tio2 & 100 & 80 & 500 & 164.2 & 0.533 & -2.95391 \\
\hline 9 & Tio2 & 100 & 120 & 500 & 341.2 & 1.645 & -2.92655 \\
\hline 10 & $\mathrm{Al2o3}$ & 80 & 40 & 500 & 128.0666667 & 0.6735 & -2.91894 \\
\hline 11 & $\mathrm{Al} 2 \mathrm{o} 3$ & 80 & 80 & 500 & 248.4333333 & 1.3735 & -2.91426 \\
\hline 12 & $\mathrm{Al} 2 \mathrm{o} 3$ & 80 & 120 & 500 & 321.0333333 & 0.826 & -2.9656 \\
\hline 13 & $\mathrm{Al} 2 \mathrm{o} 3$ & 90 & 40 & 500 & 354.5666667 & 1.4055 & -2.94144 \\
\hline 14 & $\mathrm{Al} 2 \mathrm{o} 3$ & 90 & 80 & 500 & 316.2 & 1.398 & -2.93349 \\
\hline 15 & $\mathrm{Al} 2 \mathrm{o} 3$ & 90 & 120 & 500 & 352.5 & 1.103 & -2.95594 \\
\hline 16 & $\mathrm{Al} 2 \mathrm{o} 3$ & 100 & 40 & 500 & 237.3333333 & 1.176 & -2.92422 \\
\hline 17 & $\mathrm{Al} 2 \mathrm{o} 3$ & 100 & 80 & 500 & 473.8 & 0.7485 & -2.98286 \\
\hline 18 & $\mathrm{Al} 2 \mathrm{o} 3$ & 100 & 120 & 500 & 394.0333333 & 0.8605 & -2.97236 \\
\hline 19 & Sio2 & 80 & 40 & 500 & 141.7333333 & 0.765 & -2.91654 \\
\hline 20 & Sio2 & 80 & 80 & 500 & 143.3333333 & 0.099 & -2.9983 \\
\hline 21 & Sio2 & 80 & 120 & 500 & 138.1333333 & 0.373 & -2.96339 \\
\hline
\end{tabular}




\begin{tabular}{|l|l|l|l|l|l|l|l|}
\hline 22 & Sio2 & 90 & 40 & 500 & 132.6666667 & 0.5155 & -2.9428 \\
\hline 23 & Sio2 & 90 & 80 & 500 & 299.1666667 & 0.513 & -2.98051 \\
\hline 24 & Sio2 & 90 & 120 & 500 & 509.5666667 & 1.063 & -2.97406 \\
\hline 25 & Sio2 & 100 & 40 & 500 & 136.3666667 & 0.7355 & -2.9166 \\
\hline 26 & Sio2 & 100 & 80 & 500 & 168.1 & 1.182 & -2.88815 \\
\hline 27 & Sio2 & 100 & 120 & 500 & 516.2666667 & 0.6315 & -2.98905 \\
\hline
\end{tabular}

As it is known that the columns of the OA are orthogonal to each other, the average effect of each factor on the quality characteristic at different levels can be determined. The average of the $\mathrm{S} / \mathrm{N}$ ratio for each level of the factors of $\mathrm{A}$, $\mathrm{B}$, and $\mathrm{C}$ are given in Table 8 . The delta value was calculated by subtracting the largest value from the lowest from among the values in each column.

Table 8: Response Table for Signal to Noise Ratios

\begin{tabular}{|l|l|l|l|}
\hline Level & $\begin{array}{r}\text { Nano } \\
\text { material }\end{array}$ & Temperature & Time \\
\hline 1 & -2.945 & -2.946 & -2.926 \\
3 & -2.952 & -2.945 & -2.955 \\
Delta & 0.015 & 0.003 & -2.955 \\
Rank & 2 & 3 & 0.029 \\
\hline
\end{tabular}

Very simply, a design factor with a large difference in the signal noise ratio from one factor setting to another indicates that the factor or design parameter is a significant contributor to the achievement of the performance characteristic. When there is little difference in the signal to noise ratio from one factor setting to another, this indicates that the factor is insignificant with respect to the performance characteristic. It is found from Table 8 that plating time the highest delta value and hence has the greatest influence over the wear performance of electroless Ni-P coatings. The main effect plot are illustrated in Fig.2.The main effects plot gives the optimal combination of testing parameters for minimum roughness and maximum microhardnes. 


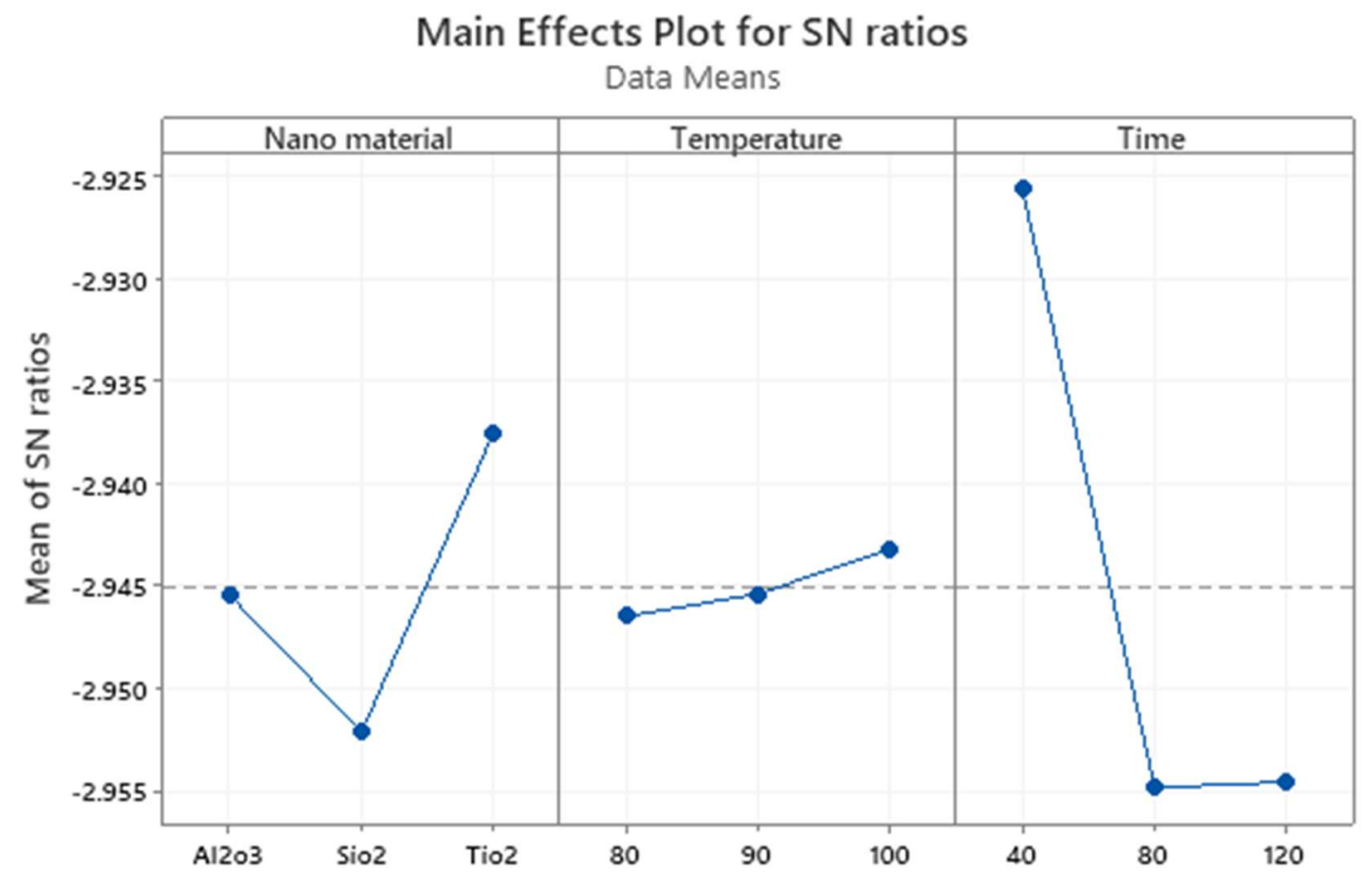

Figure 2: Main effects plot for signal to noise ratio

Since Taguchi method obtains the optimal level combination by choosing those levels for which $\mathrm{S} / \mathrm{N}$ ratio is the highest, the optimal combination of parameters is found to be $\mathrm{A} 2 \mathrm{~B} 1 \mathrm{C} 2$ i.e. middle-level of bath temperature $\left(90^{\circ} \mathrm{C}\right)$, lower level of plating time $\left(80 \mathrm{~min}\right.$.) and middle level of nanomaterial $\left(\mathrm{Al}_{2} \mathrm{O}_{3}\right)$. Moreover, the main effect plot also gives a rough idea about the relative significance of the parameters on the system response. This is determined by the slope of the main effect plot for each parameter. The plot having higher inclination will have higher influence.

ANOVA is a statistical technique to find out the significance of individual process parameters and their interactions on the system response under consideration. In the present study, ANOVA is applied with an objective to evaluate the significance of testing parameters on the microhardness and Roughness Performance of electroless Ni-P coatings. If some testing parameters do not have considerable impact on microhardness and Roughness Performance, they can be kept within a suitable range for the test and can be excluded in building future prediction and optimization models. The percentage contribution of variance can also be calculated through ANOVA. In the present study, ANOVA is performed using S/N ratio as the response and the results are shown in Table 9.

Table 9: Results of ANOVA

\begin{tabular}{|l|l|l|l|l|}
\hline \multicolumn{1}{|c|}{ Source } & DF & SS & MS & $\begin{array}{c}\% \\
\text { Contr. }\end{array}$ \\
\hline $\begin{array}{l}\text { Nano } \\
\text { material }\end{array}$ & 2 & 1.1544 & 0.5772 & 60 \\
\hline Temperature & 2 & 0.5474 & 0.2737 & 28 \\
\hline Time & 2 & 0.2332 & 0.1166 & 12 \\
\hline
\end{tabular}




\begin{tabular}{|l|l|l|l|l|}
\hline Error & 20 & 2.2582 & 0.1129 & \\
\hline Total & 26 & 4.1932 & & \\
& & & & \\
\hline
\end{tabular}

ANOVA table shows the percentage contribution of each parameter. It is seen from the table that the parameter A (Nanomaterial) has got the most significant influence on microhardness and surface roughness at confident level of $95 \%$ within the specific test range as compared with the bath temperature (12\%) and plating time (12\%).

The final step of the DOE is the confirmation test, which verifies if the optimum conditions suggested by the matrix experiment do indeed give the improvement projected. The verification experiment is performed by conducting a test with optimal settings of the factors and levels previously evaluated. The predicted value of the $\mathrm{S} / \mathrm{N}$ ratio at the optimum level $\eta$ is calculated as:

$$
\eta=\eta_{m}+\sum_{i=0}^{o}\left(\eta_{i}-\eta_{m}\right)(1-1)
$$

where $\eta_{m}$ is the total mean $\mathrm{S} / \mathrm{N}$ ratio, $\eta_{i}$ is the mean $\mathrm{S} / \mathrm{N}$ ratio at the optimal level, and $o$ is the number of main design parameters that significantly affect the wear performance of electroless Ni-P coating. Table 10 shows the comparison of the predicted $\mathrm{S} / \mathrm{N}$ ratio with the actual (experimental) $\mathrm{S} / \mathrm{N}$ ratio using the optimal parameters and there seems to be quite a good agreement between the two.

Table 10: Results of the confirmation experiment

\begin{tabular}{|l|l|l|l|}
\hline & $\begin{array}{l}\text { Initial } \\
\text { Parameters }\end{array}$ & Optimal & Experiment \\
\hline Level & A1B1C1 & A2B1C2 & A2B1C2 \\
\hline Microhardness \& Roughness & -2.92926 & -2.96347 & -3.1321 \\
\hline
\end{tabular}




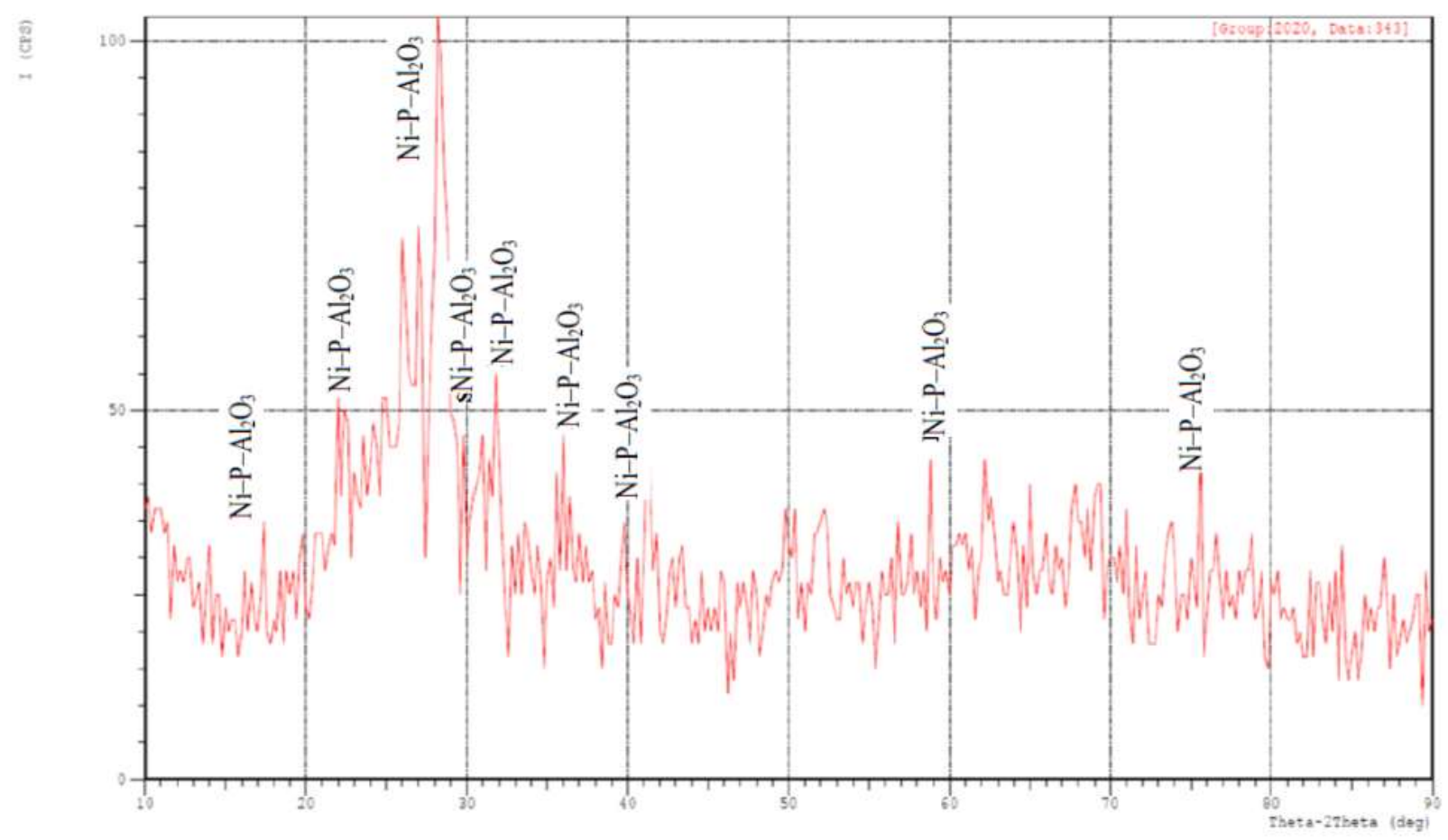

Figure 3: X-ray diffraction of electroless $\mathrm{Ni}-\mathrm{P}-\mathrm{Al}_{2} \mathrm{O}_{3}$ Coating

\section{CONCLUSIONS}

In this study Taguchi method, is successfully applied in order to optimize the electroless characteristics of Ni-P coatings. Accordingly, the following results were obtained:

- Taguchi method could be a suitable DOE for Ni-P nanocomposite coatings.

- Taguchi method showed that nanomaterial had the highest impact on the microhardness and surface roughness of Ni-P nanocomposite coatings.

- Optimal parameters for the formation of Ni-P nanocomposite coatings included A2B1C2 i.e. middle-level of bath temperature $\left(90^{\circ} \mathrm{C}\right)$, lower level of plating time $\left(80 \mathrm{~min}\right.$.) and middle level of nanomaterial $\left(\mathrm{Al}_{2} \mathrm{O}_{3}\right)$.

- The ANOVA analysis reveals that nanomaterial has a great influence over the microhardness and surface roughness performance of the coating as compared to bath temperature and plating time.

- The XRD plot revealed that the coating possesses a mixture of amorphous and crystalline structure.

\section{REFERENCES}

1. M. Palaniappa, S. K. Seshadr, Structural and Phase Transformation Behaviour of Electroless Ni-P and Ni-W-P Deposits,Materials Science and Engineering: A, 460 (2007) 638-644.

2. Z.Yin, F. Chen, Effect of Nickel Immersion Pretreatment on The Corrosion Performance of Electroless Deposited Ni-P Alloys on Aluminum, Surface and Coatings Technology, 228 (2013) 34-40.

3. J. Sudagar, J. Lian, W. Sha, Electroless Nickel, Alloy, Composite and Nano Coatings-A critical Review, Journal of Alloys and Compounds, 571 (2013) 183-204.

4. R. Parkinson, Properties and Applications of Electroless Nickel, Nickel Development Institute, 37(1997) 1-33. 
5. R. N. Duncan, Electroless Nickel: Past, Present and Future, Electroless Nickel, 93(1993), Conference, Orlando.

6. Sudagar J. Lian J, Sha W, 2013, Electroless Nickel, Alloy, Composite and Nano Coatings - A Critical Review, Jourmal of Alloys and Compounds 571, 183-204.

7. Masjedi-Arani M, Ghiyasiyan-Arani M, Amiri O, Salavati-Niasari M. CdSnO3 -graphene nanocomposites: Ultrasonic synthesis using glucose as capping agent and characterization for electrochemical hydrogen storage. Ultrason Sonochem ( 2020);61:104840.

8. Nguyen-Tri P, Nguyen TA, Carriere P, Ngo Xuan C. Nanocomposite Coatings: Preparation, Characterization, Properties, and Applications. International Journal of Corrosion. 2018:4749501-4749501.

9. Sudagar, J., Lian, J., \& Sha, W. (2013). Electroless nickel, alloy, composite and nano coatings-A critical review. Journal of Alloys and Compounds, 571, 183-204.

10. [P. Gadhari and P. Sahoo, "Electroless nickel-phosphorus composite coatings: A review," Int. J. Manuf. Mater. Mech. Eng., Vol. 6, No. 1, pp. 14-50, 2016, doi: 10.4018/IJMMME.2016010102.

11. M. Uysal, "Electroless Codeposition of Ni-P Composite Coatings: Effects of Graphene and TiO ${ }_{2}$ on the Morphology, Corrosion, and Tribological Properties," Metall. Mater. Trans. A Phys. Metall. Mater. Sci., Vol. 50, No. 5, pp. 2331-2341, 2019, doi: 10.1007/s11661-019-05161-9.

12. [M. Ram, M. Kumar, A. Ansari, S. Sharma, and A. Sharma, "Corrosion resistance of electroless Ni-P-SiC/ $\mathrm{Ni}-\mathrm{P}-\mathrm{TiO}-\mathrm{ZrO}{ }_{2}$ nano-coatings in paper mill bleach plant," Mater. Today Proc., Vol. 21, pp. 1200-1212, 2020, doi: 10.1016/j.matpr.2020.01.070.

13. M. Uysal, "Electroless Codeposition of Ni-P Composite Coatings: Effects of Graphene and TiO ${ }_{2}$ on the Morphology, Corrosion, and Tribological Properties," Metall. Mater. Trans. A Phys. Metall. Mater. Sci., Vol. 50, No. 5, pp. 2331-2341, 2019, doi: 10.1007/s11661-019-05161-9.

14. M. Ram, M. Kumar, A. Ansari, S. Sharma, and A. Sharma, "Corrosion resistance of electroless Ni-P-SiC/ Ni-P-TiO2-ZrO2 nanocoatings in paper mill bleach plant," Mater. Today Proc., Vol. 21, pp. 1200-1212, 2020, doi: 10.1016/j.matpr.2020.01.070. 